\title{
DUPLICATION OF DNA DURING THE FIRST CELL CYCLE IN THE MOUSE EMBRYO
}

\author{
G. SIRACUSA, M. COLETTA AND V. MONESI \\ Institutes of Histology and General Embryology of the University of Rome \\ and of the School of Medicine of L'Aquila, Italy
}

(Received 5th August 1974)

Microdensitometric studies of DNA content in Feulgen-stained mouse zygotes (Alfert, 1950) have shown that the pronuclei duplicate their DNA before the prophase of the first cleavage division. The earliest incorporation of labelled adenine into DNA was autoradiographically detected by Sirlin \& Edwards (1959) $13 \mathrm{hr}$ after ovulation; according to Mintz (1965), DNA synthesis takes place by the end of the first third of the cycle. In the present study, we have investigated the timing of DNA duplication in the mouse zygote. While we were analysing our data, Luthardt \& Donahue (1973) published an extensive work on pronuclear DNA synthesis in the mouse. Their findings will be discussed.

Virgin Swiss female mice (CD-1 COBS) purchased from Charles River Italia were kept in a room with controlled temperature and light conditions (lights on from 06.00 to 18.00 hours). About 2 weeks after their arrival, when the animals were 7 to 8 weeks old, superovulation was induced with an intraperitoneal injection of 5 i.u. PMSG (Gestyl: Organon) followed $46 \mathrm{hr}$ later, at 12.00 hours, by an injection of 2 i.u. HCG (APL: Ayerst). This treatment results in ovulation approximately $12 \mathrm{hr}$ after HCG (Fowler \& Edwards, 1957). Each female was placed with a male $9 \frac{1}{2} \mathrm{hr}$ after injection of HCG and was checked for vaginal plugs every $30 \mathrm{~min}$ until 23.30 hours.

Beginning $5 \mathrm{hr}$ after detection of the plug, groups of animals were killed at 2-hr intervals until $19 \mathrm{hr}$. Tubal eggs still surrounded by cumulus cells were collected and cultured in medium for mouse ova (Whittingham, 1971) containing $100 \mu \mathrm{Ci}\left[{ }^{3} \mathrm{H}\right]$ thymidine $/ \mathrm{ml}$ (N.E.N. sp. act. $20 \mathrm{Ci} / \mathrm{mmol}$ ). This high concentration of $\left[{ }^{3} \mathrm{H}\right]$ thymidine was chosen to overcome the difficulty in labelling one-cell mouse eggs in vitro (Barlow, Owen \& Graham, 1972), which is probably due to a slow penetration of the radioactive precursor at the early stages of development (Graham, 1973).

The eggs were placed in the labelled medium within 5 min of autopsy. At the end of the incubation period, the eggs were cleared of cumulus cells with hyaluronidase, repeatedly washed in medium containing an excess of cold thymidine, and eventually fixed for a few hours in cold buffered formalin; they were then transferred to water for a few hours to remove the fixative and squash preparations were made on gelatinized slides. After brief treatment with cold $5 \%$ trichloroacetic acid, the preparations were coated with autoradiographic emulsion Kodak NTB2, exposed for 10 days, and stained with Giemsa. 
Labelling times given in the text refer to the interval between detection of the vaginal plug and the end of the labelling period.

Only well-preserved embryos at the pronuclear stage were considered in this study. A total of 291 zygotes, from twenty-four females, were studied. At 6 and $8 \mathrm{hr}$, the eggs did not show any labelling (Text-fig. 1). At $10 \mathrm{hr}$, only a small fraction (3/41) of the eggs had a faint pronuclear labelling. The percentage of labelled zygotes increased $(9 / 28)$ at $12 \mathrm{hr}$ while the labelling became more intense; the smaller female pronucleus had an obviously higher grain density (Pl. 1, Fig. 1). The second polar body was also frequently labelled. Pronuclear labelling remained heavy in a large fraction of the zygotes at 14 and $16 \mathrm{hr}$ (29/38 and 26/41 respectively), and declined both in percentage (6/45) and in intensity at $18 \mathrm{hr}$. Of the six embryos labelled at $18 \mathrm{hr}$, three were labelled over only one pronucleus (PI. 1, Fig. 2). Pronuclear labelling was no longer present at $20 \mathrm{hr}$ after a plug was detected; at this time in most of the embryos (18/30), only the second polar body continued to incorporate thymidine.

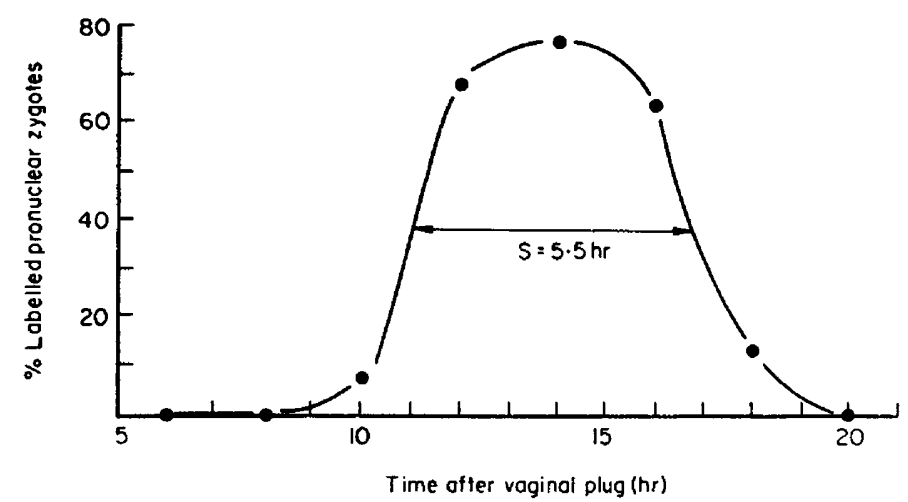

TEXT-pIG. 1. Percentage of pronuclear mouse zygotes labelled with $\left[{ }^{3} \mathrm{H}\right]$ thymidine at various times after mating.

The first autoradiographic signs of pronuclear DNA duplication were detected $10 \mathrm{hr}$ after mating, and duplication was completed within $18 \mathrm{hr}$ (Text-fig. 1); the peak of labelled eggs occurred at $14 \mathrm{hr}$, at which time $76 \%$ of the pronuclear eggs showed labelling over both pronuclei. The $50 \%$ intercept values (drawn by eye) give an estimate for the duration of the S-period of $5 \frac{1}{2} \mathrm{hr}$ (from 11.20 to $16.50 \mathrm{hr}$ after vaginal plug). This estimate is $1 \frac{1}{2} \mathrm{hr}$ longer than that obtained by Luthardt \& Donahue (1973), whose data indicate an S-period lasting approximately from 23 to $27 \mathrm{hr}$ after HCG. The reason for this discrepancy is not clear. Strain differences might be involved. The interval of $1 \mathrm{hr}$ which elapsed in their experiments between killing the mother and incubation of the eggs in the labelled medium, together with the pre-labelling hyaluronidase treatment might also have influenced the rate of DNA replication. Differences in the concentration and specific activity of the labelled precursor might have caused differences in the ability to detect the beginning and end of replication. A more important difference is that Luthardt 
PLATE I

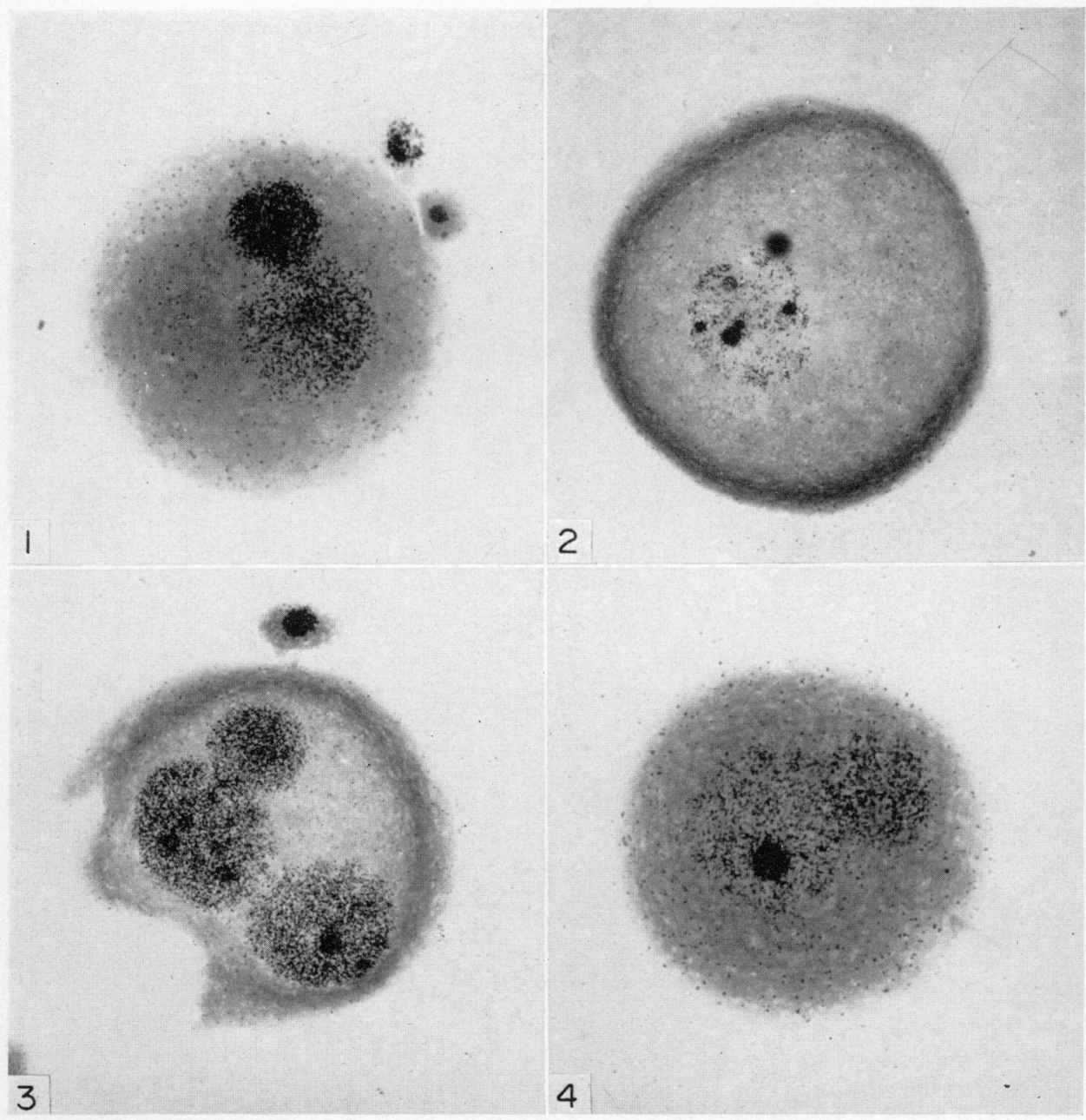

FIG. 1. Mouse zygote incubated in $\left[{ }^{3} \mathrm{H}\right]$ thymidine from 11 to $12 \mathrm{hr}$ after detection of a vaginal plug. Both pronuclei are labelled; the smaller female pronucleus shows a higher grain density; the second polar body is labelled. $\times 375$.

Fig. 2. Mouse zygote incubated 17 to $18 \mathrm{hr}$ after detection of a plug. Only one pronucleus is labelled; the nucleoli are very heavily labelled. $\times 300$.

FIG. 3. A dispermic mouse zygote incubated 15 to $16 \mathrm{hr}$ after detection of a plug. The three pronuclei and the nucleoli in the male pronuclei are labelled. $\times 300$.

FIG. 4. Mouse zygote incubated 13 to $14 \mathrm{hr}$ after detection of a plug. The male pronucleus shows a heavily labelled nucleolus. $\times 375$. 
\& Donahue caged the females with males immediately after HCG injection and checked for vaginal plugs $13 \mathrm{hr}$ later. Since ovulation following HCG administration occurs between 11 and $14 \mathrm{hr}$ (Edwards \& Gates, 1959), this procedure might have given greater asynchrony in fertilization among eggs. We have operated under more stringent time conditions, referring the data to the interval between mating and labelling, and we may therefore expect the asynchrony among our eggs to be smaller, as the shape of the curve indicates.

The duration of DNA replication in the mouse pronuclei seems longer than in the rabbit, for which estimates between 1 and $4 \mathrm{hr}$ were obtained (Oprescu \& Thibault, 1965; Szollosi, 1966).

A slight asynchrony in DNA replication between the male and female pronuclei, the male pronucleus beginning and ending replication before the female one, was found by Sirlin \& Edwards (1959) and by Luthardt \& Donahue (1973). In the mouse, the larger male pronucleus can be easily identified (Edwards \& Sirlin, 1956; Donahue, 1972). Our data seem to support the existence of an asynchrony since at the later times some embryos were labelled over one pronucleus, but it was difficult in these preparations to identify the two pronuclei. More detailed studies are needed for a more precise definition of the degree of asynchrony.

A considerable asynchrony was also found between labelling of the pronuclei and of the second polar body (PB). In the mouse, the first PB shows signs of chromosomal degeneration as early as telophase I (Donahue, 1968; McGaughey \& Chang, 1969). Labelling of the second PB has already been observed in the zygotes of rabbits (Szollosi, 1966) and mice (Luthardt \& Donahue, 1973). The duplication begins in the PB probably later than in the pronuclei, and lasts much longer: $60 \%$ of the eggs still showed PB labelling at $20 \mathrm{hr}$, when DNA duplication in the pronuclei had apparently ceased. Labelling was found in PB by Gamow \& Prescott (1970) as late as the two-cell mouse embryo. These data contradict the view commonly held that DNA synthesis in the PB is a rather rare event (Mintz, 1964).

One of the embryos showing pronuclear labelling was dispermic $(\mathrm{Pl} .1$, Fig. 3); the observation of a triploid zygote is not uncommon in the mouse, in which it occurs with a frequency of about $1 \%$ (Braden, 1957; Donahue, 1972). Luthardt \& Donahue (1973) observed five triploid eggs labelled over all three pronuclei, and did not find any difference with respect to time of pronuclear labelling. Our dispermic egg was also labelled over the three pronuclei.

An unexpected finding of this study was that the nucleoli of the pronuclei were frequently heavily labelled with $\left[{ }^{3} \mathrm{H}\right]$ thymidine. The labelling was often so intense that autoradiographic grains could not be easily resolved, and whole nucleolar areas appeared completely blackened (PI. 1, Figs 2, 3 and 4). Both primary and secondary nucleoli (Austin, 1951) were found labelled in a fraction of the zygotes; the labelling was more evident in the male pronuclei.

Autoradiography of semi-thin sections of plastic-embedded material revealed the labelling to be clearly limited to the periphery of the nucleoli, while the core was not labelled. The labelling is presumably due to a high concentration of chromatin, possibly constitutive heterochromatin, surrounding the nucleoli. Cytological hybridization studies are under progress to test this hypothesis. 
This work was supported by Grant No. 730-0208 from the Ford Foundation and by Grant No. 73.00673.04 from the Consiglio Nazionale delle Richerche.

\section{REFERENCES}

Alfert, M. (1950) A cytochemical study of oogenesis and cleavage in the mouse. $\mathcal{F}$. cell. comp. Physiol. 36, 381-409.

Austin, C. R. (1951) The formation, growth and conjugation of the pronuclei in the rat egg. $\mathscr{f l} R$. microst. Soc. 71, 295-306.

Barlow, P., Owen, D. A. J. \& Graham, C. (1972) DNA synthesis in the preimplantation mouse embryo. 7. Embryol. exp. Morph. 27, 431-445.

BRADEN, A. W. H. (1957) Variation between strains in the incidence of various abnormalities of egg maturation and fertilization in the mouse. 7 . Genet. 55, 476-486.

Donahue, R. P. (1968) Maturation of the mouse oocyte in vitro. I. Sequence and timing of nuclear progression. 7. exp. Zool. 169, 237-250.

Donahue, R. P. (1972) Cytogenetic analysis of the first cleavage division in mouse embryos. Proc. natn. Acad. Sci. U.S.A. 69, 74-77.

Edwards, R. G. \& Gates, A. H. (1959) Timing of the stages of the maturation divisions, ovulation, fertilization and first cleavage of eggs of adult mice treated with gonadotrophins. $\mathcal{F}$. Endocr. 18, 292-304.

Edwards, R. G. \& Sirtin, J. L. (1956) Labelled pronuclei in mouse eggs fertilized by labelled sperm. Nature, Lond. 177, 429.

Fowler, R. E. \& EDWARDs, R. G. (1957) Induction of superovulation and pregnancy in mature mice by gonadotrophins. F. Endocr. 15, 374-384.

Gamow, E. I. \& Prescotr, D. M. (1970) The cell life cycle during early embryogenesis in the mouse. Expl Cell Res. 59, 117-123.

Grahas, C. F. (1973) Nucleic acid metabolism during early mammalian development. In The Regulation of Mammalian Reproduction, pp. 286-298. Eds. S. J. Segal, R. Crozier and P. Corfman. National Institutes of Health Monograph.

Luthardt, F. W. \& Donahue, R. P. (1973) Pronuclear DNA synthesis in mouse eggs. An autoradiographic study. Expl Cell Res. 82, 143-151.

MoGaughey, R. W. \& Chang, M. C. (1969) Meiosis of mouse eggs before and after sperm penetration. 7. exp. Zool. 170, 397-410.

Mintz, B. (1964) Synthetic processes and early development in the mammalian egg. J. exp. Zool. 157, $85-100$.

Mintz, B. (1965) Nucleic acid and protein synthesis in the developing mouse embryo. In Preimplantation Stages of Pregnancy, pp. 145-161. Ed. G. E. W. Wolstenholme. Churchill, London.

Oprescu, S. \& Thibault, C. (1965) Duplication de l'ADN dans les oeufs de lapine après la fécondation. Annls Biol. anim. Biochim. Biophys. 5, 151-156.

Sirlin, J. I. \& EDwards, R. G. (1959) Timing of DNA synthesis in ovarian oocyte nuclei and pronuclei of the mouse. Expl Cell Res. 18, 190-194.

Szollosi, D. (1966) Time and duration of DNA synthesis in rabbit eggs after sperm penetration. Anat. Rec. 154, 209-212.

Whittingham, D. G. (1971) Culture of mouse ova. J. Reprod. Fert., Suppl. 14, 7-21. 